\title{
Analisis Kemampuan Berpikir Matematis Siswa SMA Kota Sorong terhadap Butir Soal dengan Graded Response Model
}

\author{
Muhammad Syahrul Kahar \\ Fakultas Keguruan dan Ilmu Pendidikan, Universitas Muhammadiyah Sorong; \\ muhammadsyahrulkahar@gmail.com
}

Diterima: 6 April 2017. Disetujui: 27 Mei 2017. Dipublikasikan: Juni 2017

\begin{abstract}
This research aims to know the level of mathematical thinking ability of students by using scored model Graded Response Model (GRM). The subject here is the students of Class XI IPA 1 SMA Negeri 3 Sorong the 2016/2017 academic year, which amounted to 38 students with 22 students are male and 16 female students. This research is a descriptive research experiment. The results of this study indicate that the scored model GRM is effective in analyzing the ability of mathematical thinking of students. The effectiveness is shown an increase in student learning outcomes grade XI IPA 1 SMA Negeri 3 Kota Sorong, where the average grade results visible increase of 56.7 until 78, and the value of the completeness students improved significantly, and student learning outcomes were shown in graded contents relevance criteria students with score 4 there are 18 students (47.37\%), while the relevance of the contents with a score of 1 there are 4 students (10.53\%). From the criteria of completeness students who achieve complete answers by a score of 4, there are 1 students (2.64\%), and the answers are far from finished with a score of 1 there were 7 students (19.52\%). Then to organizing criteria, students are working on a very systematic, there are 8 students $(21.05 \%)$, and organizing with not systematically there are 10 students $(26.32 \%)$.
\end{abstract}

\begin{abstract}
Abstrak
Penelitian ini bertujuan untuk mengetahui tingkat kemampuan berpikir matematis siswa dengan menggunakan model penyekoran Graded Response Model (GRM). Subjek penelitian disini adalah siswa kelas XI IPA 1 SMA Negeri 3 Kota Sorong tahun ajaran 2016/2017, yang berjumlah 38 siswa dengan 22 siswa laki-laki dan 16 siswa perempuan. Penelitian ini adalah penelitian eksperimen yang bersifat Deskriptif. Hasil penelitian ini menunjukkan bahwa model penyekoran GRM ini efektif dalam menganalisis kemampuan berpikir matematis siswa. Keefektifan tersebut terlihat adanya peningkatan hasil belajar siswa kelas XI IPA 1 SMA Negeri 3 Kota Sorong, dimana hasil rerata kelas terlihat meningkat dari 56,7 hingga 78, dan nilai ketuntasan siswa meningkat secara signifikan, dan hasil belajar siswa dilihat secara graded dengan kriteria relevansi isi dengan skor 4 terdapat 18 siswa (47,37\%), sementara relevansi isi dengan skor 1 terdapat 4 siswa $(10,53 \%)$. Dari kriteria ketuntasan siswa yang mencapai jawaban tuntas dengan skor 4 terdapat 1 siswa (2,64\%), dan jawaban jauh dari tuntas dengan skor 1 terdapat 7 siswa (19,52\%). Kemudian untuk kriteria pengorganisasian, siswa mengerjakan dengan sangat sistematis terdapat 8 siswa $(21,05 \%)$, dan pengorganisasian dengan tidak sistematis terdapat 10 siswa $(26,32 \%)$.
\end{abstract}

Kata Kunci: GRM model, kemampuan berpikir matematis, model graded response

(C) 2017 URPI, FTK IAIN Raden Intan Lampung

\section{PENDAHULUAN}

Matematika merupakan salah satu pelajaran yang memiliki karakter tertentu, karakteristik matematika sangat memerlukan kemampuan mental yang tinggi dan perhatian suatu teorema atau defenisi, dalam mempelajari mata pelajaran matematika memerlukan waktu yang relatif lama dan memerlukan ketekunan serta kesungguhan untuk dapat memahami materi. Namun hal tersebut juga yang menyebabkan matematika merupakan pelajaran yang kurang diminati siswa. Perkembangan ilmu pengetahuan yang menuntut siswa untuk dapat berpikir 
kritis, sistematis, logis, dan kreatif memang tidak dapat dipungkiri lagi. Cara berpikir seperti ini dapat dikembangkan dengan belajar matematika, karena matematika memiliki struktur dan keterkaitan yang kuat dan jelas antar konsepnya sehingga memungkinkan siswa terampil berpikir rasional.

Depdiknas menjelaskan bahwa Matematika berfungsi mengembangkan kemampuan berhitung, mengukur, menganalisis dan menggunakan rumus (Depdiknas, 2005). Matematika juga berfungsi mengembangkan kemampuan mengkomunikasikan gagasan dengan bahasa yang dapat berupa model matematika, kalimat matematika, diagram, grafik atau tabel.

Cornelius mengatakan bahwa ada banyak alasan tentang perlunya siswa belajar matematika, yaitu: 1) Merupakan sarana berpikir yang logis, 2) Sarana memecahkan masalah kehidupan seharihari, 3) Sarana mengenal pola-pola hubungan dan generalisasi pengalaman, dan 4) Sarana mengembangkan kreatifitas (Cornelius, 2000).

Begitu pentingnya peranan matematika seperti uraian di atas seharusnya membuat matematika menjadi salah satu mata pelajaran yang menyenangkan dan digemari oleh siswa. Namun seperti halnya disebutkan di atas, masih banyak siswa yang menganggap matematika itu sulit dan membosankan sehingga menimbulkan masalah dalam belajar.

Slameto mengatakan belajar intensional (intentional learning) yang artinya belajar dalam arah tujuan, merupakan awal dari belajar incidental yang akan dibahas lebih luas pada bagian berikutnya, hal tersebut merupakan salah satu bukti bahwa saat belajar dalam hal ini belajar matematika pun harus adanya suatu kesistematisan dan kita diharapkan untuk berpikir kritis (Slameto, 2010).

Sanjaya mengatakan isi atau materi pelajaran merupakan komponen kedua dalam sistem pembelajaran (Sanjaya,
2006). Namun dalam konteks tertentu, materi pelajaran merupakan inti dalam proses pembelajaran. Artinya, sering terjadi pembelajaran diartikan dengan penyampaian materi. Hal ini bisa dibenarkan manakala tujuan utama pembelajaran adalah penguasaan materi pelajaran (subject centered teaching).

Sementara itu menurut (Sabandar, 2008) belajar matematika berkaitan dengan aktifitas dan proses belajar serta berpikir karena karakteristikmatematika merupakan suatu ilmu dan human actifity (yaitu bahwa matematika adalah pola berpikirdan pola mengorganisasikan pembuktian yang logis). Matematika juga menggunakan istilah-istilah yang harus didefenisikan dengan cermat, jelas, dan akurat, sehingga siswa yang mengikuti pembelajaran matematika diharapkan dapat memiliki kemampuan berpikir matematis.

Kemampuan berpikir matematis khususnya berpikir matematis tingkat tinggi (high order mathematical thinking) sangat diperlukan siswa, terkait dengan kebutuhan siswa untuk memecahkan masalah yang dihadapinya sehari-hari (Meltzer, 2002). Keterampilan berpikir tingkat tinggi, khususnya kritis cenderumg diukur baik dengan tes khusus ataupun tes yang dikaitkan dengan materi tertentu. Untuk mengukur kemampuan berpikir perlu dipertimbangkan alasan dan sumber yang menjadi pacuan siswa untuk menjawab pertanyaan tersebut. Format tes dalam bentuk uraian dapat berguna menilai bagaimana siswa mencapai dan menjelaskan kesimpulan mereka.

Noer menjelaskan dalam penyekoran Graded Response Model (GRM) (Noer, 2009), merupakan salah satu pendekatan model IRT (item respon theory) dimana bertujuan untuk menampilkan kemampuan berpikir matematis siswa, karena bentuk tes yang digunakan dalam penyekoran model ini adalah uraian, yang menuntut siswa untuk mampu berpikir kritis, dan setiap butir soal dibuat berdasarkan tingkat kesulitan dari mudah hingga sukar. 


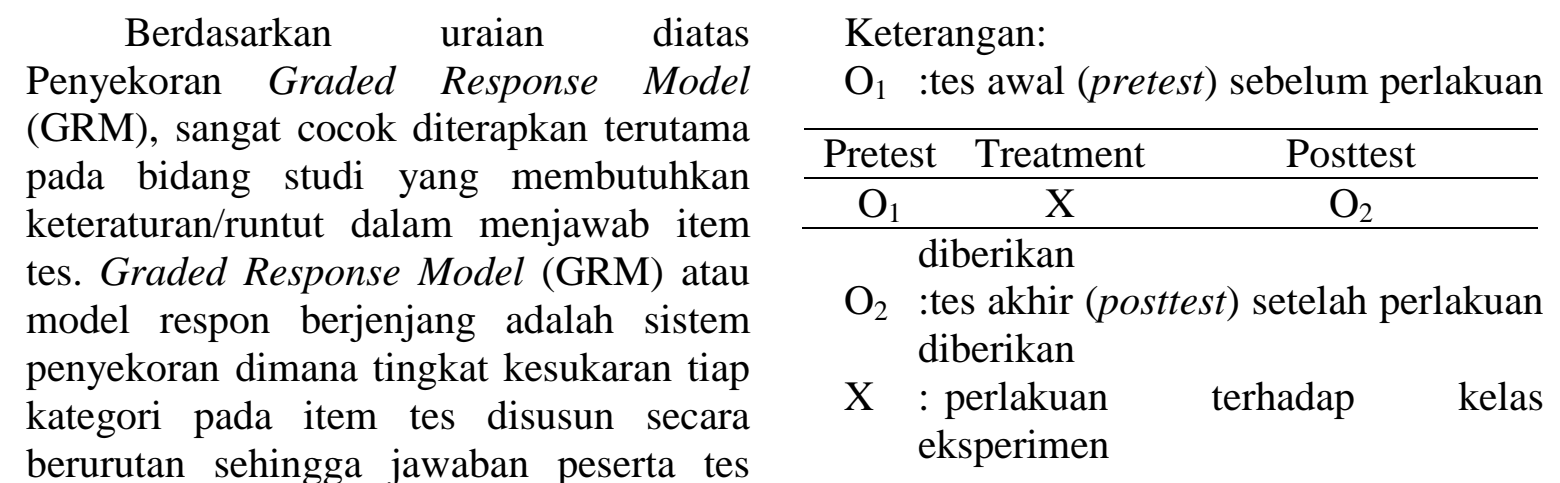
haruslah terurut dari kategori yang rendah hingga kategori yang tinggi.

Hal ini sejalan dengan penelitian (Matteuci \& Staqcuarusi, 2006) mengatakan bahwa Graded Response Model (GRM) merupakan salah satu model Item Response Theory (IRT) untuk data politimus (data yang memiliki banyak nilai). Graded Response Model (GRM) digunakan dengan tujuan menampilkan estimasi parameter butir dan kemampuan siswa.

\section{METODE PENELITIAN}

Metode yang digunakan dalam penelitian ini adalah pre-eksperimen. Sugiyono mengatakan bahwa "penelitian pre-eksperimen hasilnya merupakan variabel dependen bukan semata-mata dipengaruhi oleh variabel independen". Hal ini dapat terjadi, karena tidak adanya veriabel kontrol, dan sampel tidak dipilih secara random (Sugiyono, 2010).

Desain penelitian merupakan rancangan bagaimana penelitian dilaksanakan. Desain penelitian yang digunakan dalam penelitian ini adalah one group pretest posttest design. Desain ini digunakan sesuai dengan tujuan yang hendak dicapai yaitu ingin mengetahui peningkatan kemampuan berpikir matematis siswa setelah diterapkan penyekoran GRM. Berikut tabel desain penelitian one group pretest posttest design (Sugiyono, 2008).

Tabel 1. Desain penelitian one group pretest posttest design
Populasi dari penelitian ini adalah siswa kelas XI IPA SMA Negeri 3 Kota Sorong, yang berjumlah 230 siswa, sedangkan sampel dari penelitian adalah 1 kelas, dimana diambil secara Purpose Sampling yang berarti pengambilan sampel secara sengaja, dimana peneliti hanya akan meneliti kemampuan berpikir matematis siswa dengan rerata kelas paling tinggi dimana informasi didapat dari guru matematika yang mengajar di SMA N 3 Kota Sorong yaitu kelas XI IPA 1 yang berjumlah 38 siswa.

Variabel penelitian pada dasarnya adalah segala sesuatu yang berbentuk apa saja yang ditetapkan oleh peneliti untuk dipelajari sehingga diperoleh informasi tentang hal tersebut. Variabel penelitian ini adalah kemampuan berpikir matematis dari subjek penelitian, yaitu siswa kelas XI IPA 1 SMA Negeri 3 Kota Sorong.

Instrumen yang digunakan dalam penelitian ini adalah: (1) tes hasil belajar, (2) format validasi untuk tiap instrumen (validitas internal dan eksternal). Pemeriksaan validitas isi (content validity) telah dilakukan oleh berbagai pihak yang berkompeten dalam instrumen ini. Instrumen tes hasil belajar kognitif dan kuesioner kesadaran metakognitif diperiksa oleh dua orang pakar dalam bidang pendidikan matematika yang juga merupakan dosen jurusan Matematika.

Kriteria pengujian yang digunakan oleh para validator pada kedua macam instrumen ini adalah (1) tidak relevan, (2) kurang relevan, (3) cukup relevan, dan (4) sangat relevan. Penelitian validitas isi secara keseluruhan dengan pengategorian 
genap (skala empat) dengan menggunakan validitas isi Gregory yang memberikan metode menentukan validitas isi menyeluruh (overall) berdasarkan Judgement of Experts, yaitu berupa koefisien validitas isi. Skala 4 digunakan yang dikotomikan menjadi relevansi lemah (nilai 1 dan 2) melawan relevansi kuat (nilai 3 dan 4).

Tes hasil belajar. Tes digunakan untuk mengukur hasil belajar kognitif. Instrumen tes berupa essai sesuai dengan kisi-kisi tes. Hasil belajar kognitif yang diukur melalui tes ini adalah meliputi ranah kognitif (Anderson \& Krathwohl, 2010) yang kemudian peneliti batasi meliputi kemampuan mengingat, memahami dan menerapkan.

Instrumen tes disusun oleh peneliti dan pengembangannya meliputi: penentuan standar kompetensi, analisis kompetensi dasar, penyusunan kisi-kisi, penyusunan tes, uji ahli dan uji lapangan untuk penentuan validitas, reliabilitas, daya beda dan tingkat kesukaran. Pelaksanaan uji coba lapangan dilakukan sebelum penelitian eksperimen dilakukan. Uji coba dilakukan terhadap siswa kelas XI IPA1 SMA Negeri 3 Kota Sorong yang tidak digunakan sebagai eksperimen penelitian dan telah memperoleh materi yang diteliti.

Soal tes yang digunakan dalam penelitian ini, dilakukan uji coba terlebih dahulu, soal tes tersebut berupa tes objektif essai. Soal-soal tes dibuat oleh peneliti dan didiskusikan dengan dosen pembimbing menyangkut validasi isi dan kejelasan bahasa agar mudah dipahami siswa. Adapun kategori validitasnya sebagai berikut:

$5 \leq \mathrm{x}<8$ Tidak baik

$9 \leq \mathrm{x}<12$ Kurang baik

$13 \leq \mathrm{x}<16$ Baik

$17 \leq \mathrm{x}<20$ Sangat baik

Dengan $\mathrm{x}=$ rerata penilaian.

Reliabilitas Instrumen. Pengujian reliabilitas instrumen tes menggunakan koefisien reliabilitas dengan menggunakan rumus Alpha Cronbach (Sugiyono, 2005). Penghitungannya dengan cara manual rumus Alpha sebagai berikut:

$$
R_{l}=\frac{K}{K-1}\left\{1-\frac{\sum S t^{2}}{S t^{2}}\right\}
$$

Keterangan:

$R_{l} \quad:$ Reliabilitas instrument

$K \quad$ : Rerata kuadrat kesalah

$\begin{array}{ll}\sum_{S t^{2}} S t^{2} & : \text { Jumlah rerata kuadrat kesalahan } \\ & : \text { Varians total }\end{array}$

Kriteria uji menurut (Arikunto, 2001) adalah:

$$
\begin{aligned}
& 0,80-1,00=\text { sangat tinggi } \\
& 0,60-0,79=\text { tinggi } \\
& 0,40-0,59=\text { cukup } \\
& 0,20-0,39=\text { rendah } \\
& 0,00-0,19=\text { sangat rendah }
\end{aligned}
$$

Pengolahan data kuantitatif dilakukan dengan menggunakan uji statistik terhadap hasil data Pretest dan Posttest dari kelas eksperimen, dan hipotesis dilihat dari hasil rerata pretest maupun posttest kelas eksperimen setelah sebelumnya dilakukan pengujian normalitas data dan homogenitas untuk menentukan apakah dalam pengujian hipotesis digunakan Statistik Parametrik atau non Parametrik.

Perhitungan N-Gain diperoleh dari skor Pretest dan Posttest Peningkatan kompetensi yang terjadi sebelum dan sesudah pembelajaran dihitung dengan rumus $g$ faktor $(N$-Gain) dengan rumus menurut Meltzer (2002)adalah sebagai berikut:

$$
g=\frac{\text { Skor Postest }- \text { Skor Prestest }}{\text { Skor Ideal }- \text { Skor Pretest }}
$$

Keterangan:

$$
\begin{aligned}
& S_{\text {post }}=\text { Skor Posttest } \\
& S_{\text {pre }}=\text { Skor Pretest } \\
& S_{\text {maks }}=\text { Skor maksimum }
\end{aligned}
$$

Interpretasi N-Gain menurut (Hake, 2002) disajikan pada tabel 2 berikut: 
Tabel 2. Interpretasi N-Gain

\begin{tabular}{ll}
\hline \multicolumn{2}{c}{ Besar Persentase Interpretasi (\%) } \\
\hline $\mathrm{g}>0,7$ & Tinggi \\
\hline $0,3<\mathrm{g}<0,7$ & Sedang \\
\hline $\mathrm{g}<0,3$ & Rendah \\
\hline
\end{tabular}

\section{HASIL DAN PEMBAHASAN}

Pada penelitian ini, peneliti melakukan analisis hasil belajar siswa. Kegiatan yang dilakukan ada dua tahap penilaian yaitu pretest dan posttest terhadap siswa kelas XI IPA 1 SMA N 3 Kota Sorong dengan pokok bahasan Barisan dan Deret Geometri Tak Hingga menggunakan penyekoran Graded Response Model. Hasil pada penelitian tersebut disajikan pada Tabel 3. berikut:

Tabel 3. Statistik Skor Hasil Tes Siswa

\begin{tabular}{lll}
\hline Statistik & Pretest & Posttest \\
\hline Subjek & 38 & 38 \\
Nilai ideal & 100 & 100 \\
Nilai tertinggi & 74 & 100 \\
Nilai terendah & 30 & 55 \\
Rentang nilai & 44 & 45 \\
Rerata nilai & 56,7 & 78 \\
Standar deviasi & 19,02 & 9,96 \\
\hline
\end{tabular}

Berdasarkan Tabel 3, menunjukkan bahwa nilai rerata siswa naik secara signifikan yaitu dari 56,7 menjadi 78. Pada tes akhir ada siswa yang mampu menyelesaikan soal hingga mendapat skor 100, namun demikian masih ada siswa yang memperoleh nilai terendah yaitu 55 . Berdasarkan hasil penelitian pada pemeriksaan lembar jawaban siswa, rendahnya nilai banyak yang disebabkan oleh kurangnya penjabaran siswa.
Tes Hasil Belajar. Setelah melakukan penelitian, maka terlihat hasil tes belajar siswa dari pretest ke posttest. Pada pretest ada satu orang siswa dengan nilai terendah yaitu 30 dimana nilai tersebut jelas jauh dari nilai KKM yang sudah ditentukan yaitu 75 , dilain sisi hasil posttest bahkan ada satu orang siswa yang mencapai nilai ideal yaitu 100 .

Hasil analisis ini menunjukkan bahwa standar deviasi siswa pada hasil menurun dari 19,02 menjadi 9,96 atau turun sebanyak 9,06 dengan skor ideal 100 , hal tersebut menandakan data hasil belajar siswa semakin membaik dan menyebar mendekati nilai ideal yaitu 100 tersebut, kemudian memiliki peningkatan nilai terendah pada hasil pretest dari 30 berubah menjadi 55 pada hasil posttest, sementara peningkatan nilai tertinggi pada hasil pretest dari 74 berubah menjadi 100 pada hasil posttest.

Validitas Instrumen. Validitas berkenaan dengan ketepatan alat ukur terhadap konsep yang diuji sehingga benar-benar menguji apa yang diuji. Uji validitas dilakukan dengan tujuan untuk menunjukkan tingkat kevalidan atau kesahihan instrumen yang akan digunakan dalam penelitian. Pada penelitian ini peneliti menggunakan uji validitas ahli, dimana instrumen telah divalidasi oleh 3 validator yang dianggap ahli. Hasil validitas instrumen tersebut dapat dilihat pada Tabel 4. berikut:

Tabel 4. Validasi Instrumen Tes

\begin{tabular}{lccc}
\multicolumn{1}{c}{ Aspek yang dinilai } & \multicolumn{2}{c}{ Penilai } \\
& V1 & V2 & V3 \\
\hline Kelengkapan format instrumen evaluasi & 1 & 4 & 4 \\
Perumusan instrumen evaluasi & 2 & 3 & 4 \\
Manfaat hasil penelitian & 3 & 4 & 4 \\
Pertanyaan soal dalam instrumen evaluasi & 4 & 4 & 4 \\
Keterbacaan tulisan dan bahasa & 3 & 4 & 4 \\
\hline Jumlah & 13 & 15 & 20 \\
\hline Rerata & & 16 & \\
\hline
\end{tabular}


Berdasarkan hasil rerata validitas pada Tabel 4. di atas terlihat bahwa instrumen pada penelitian ini memiliki skor 16 atau termasuk kategori baik.

Realibilitas Instrumen. Perhitungan reliabilitas dilakukan untuk menguji keajegan penelitian. Reliabilitas berhubungan dengan masalah ketepatan atau kekonsistenan tes. Reliabilitas berarti bahwa suatu instrumen cukup dapat dipercaya untuk dapat digunakan sebagai alat pengampu data karena instrumen tersebut sudah baik.

Hasil uji reliabilitas terhadap instrumen penelitian pada sampel sebanyak 38 siswa memiliki reliabilitas yang sangat tinggi dengan koefisien reliabilitas $\left(r_{11}\right)$ sebesar 1,24. Berdasarkan perhitungan di atas, instrumen dapat dikonsultasikan dengan $r$ tabel yaitu pada taraf signifikan $(\propto)=5 \%$ adalah 0,632 .

Kesimpulannya dengan reabilitas $r_{11}$ $=1,24$ pada akhirnya dapat dinyatakan bahwa tes hasil belajar sudah memiliki reabilitas yang tinggi, yaitu $>0,63$.

Nilai N-Gain. Pengolahan data kuantitatif dilakukan dengan menggunakan uji statistik terhadap hasil data Pretest dan Posttest dari kelas eksperimen, Perhitungan N-Gain diperoleh dari skor Pretest dan Posttest dengan menggunakan rumus $g$ faktor (N-Gain) dan diperoleh hasil yang dapat dilihat dari Tabel 5 berikut:

Tabel 5. Hasil Perhitungan N-Gain

\begin{tabular}{ccc}
\hline Besar Persentase $(\%)$ & $\mathrm{f}$ & Interpretasi \\
\hline $\mathrm{g}>0,7$ & 3 & Tinggi \\
$0,3<\mathrm{g}<0,7$ & 27 & Sedang \\
$\mathrm{g}<0,3$ & 8 & Rendah \\
\hline
\end{tabular}

Berdasarkan Tabel 5. terlihat bahwa terdapat 3 siswa dengan nilai interpretasi tinggi, 27 siswa dengan nilai interpretasi sedang, dan 8 siswa dengan interpretasi rendah

Tabel 6. Distribusi Frekuensi dan Persentase Skor Siswa

\begin{tabular}{llllll}
\hline \multirow{2}{*}{ Nilai } & Kategori & \multicolumn{2}{c}{ frekuensi } & \multicolumn{2}{c}{ Persentase (\%) } \\
\cline { 3 - 6 } & Pretest & Posstest & Pretest & Posstest \\
\hline $0-54$ & Sangat rendah & 18 & - & $47,00 \%$ & - \\
$55-64$ & Rendah & 14 & 2 & $38,00 \%$ & $5,26 \%$ \\
$65-79$ & Sedang & 6 & 17 & $15,00 \%$ & $44,74 \%$ \\
$80-89$ & Tinggi & - & 11 & - & $28,95 \%$ \\
$90-100$ & Sangat tinggi & - & 8 & - & $21,05 \%$ \\
\hline & Jumlah & 38 & 38 & 100,00 & 100,00 \\
\cline { 2 - 6 }
\end{tabular}

Berdasarkan Tabel 6. di atas, kategori sangat tinggi tidak ada pada hasil pretest dan mengalami perubahan sebanyak 8 siswa pada tahap pretest.
Sebaliknya, pada hasil posttest tidak ada siswa dengan hasil kategori sangat rendah.

Jika hasil tersebut dianalisis, maka persentase kelulusan kelas eksperimen dapat dilihat pada Tabel 7. berikut:

Tabel 7. Deskripsi Ketuntasan Belajar siswa

\begin{tabular}{llllll}
\hline \multirow{2}{*}{ Nilai } & & \multicolumn{2}{c}{ frekuensi } & \multicolumn{2}{c}{ Persentase (\%) } \\
\cline { 3 - 6 } & Kategori & Pretest & Posstest & Pretest & Posstest \\
\hline $0-74$ & Tidak Tuntas & 38 & 11 & $100 \%$ & $28,94 \%$ \\
$75-100$ & Tuntas & - & 27 & - & $71,06 \%$ \\
\hline & Jumlah & 38 & 38 & $100 \%$ & $100 \%$ \\
\cline { 2 - 6 }
\end{tabular}

Tabel 7, menunjukkan bahwa pada hasil pretest siswa tidak satupun yang mencapai KKM, hal ini menandakan bahwa pada keseharian sebelumnya siswa belum terbiasa mengerjakan soal matematika dengan menggunakan GRM, namun pada hasil posttest sekalipun terlihat masih ada 11 siswa $(28,94 \%)$ yang 
belum mencapai KKM, berdasarkan wawancara secara langsung oleh peneliti dengan peserta didik diperoleh informasi bahwa pada saat pelaksanaan posttest peserta didik tidak berkonsentrasi karena dipengaruhi oleh lingkungan.

Uji Hipotesis. Ha diterima jika terdapat perbedaan rerata hasil belajar siswa sebelum penerapan penyekoran GRM dengan setelah pembelajaran dengan penerapan penyekoran GRM, dan ditolak jika tidak terdapat perbedaan rerata hasil belajar siswa sebelum penerapan penyekoran GRM dengan setelah pembelajaran dengan penerapan penyekoran GRM.

Ho diterima jika tidak terdapat perbedaan rerata hasil belajar siswa sebelum penerapan penyekoran GRM dengan setelah pembelajaran dengan penerapan penyekoran GRM, dan ditolak jika tidak terdapat perbedaan rerata hasil belajar siswa sebelum penerapan penyekoran GRM dengan setelah pembelajaran dengan penerapan penyekoran GRM.Adapun rerata hasil belajar siswa dapat dilihat pada Tabel 8 . berikut:

Tabel 8. Rerata Hasil Belajar Siswa

\begin{tabular}{ccc}
\hline Kelas & Pretest & Posttest \\
\hline Eksperimen & 56,7 & 78 \\
\hline
\end{tabular}

Berdasarkan Tabel 8, terlihat bahwa terdapat perbedaan hasil rerata siswa pada tes pretest dan posttest. Adapun uji statistiknya yang dilakukan dengan uji $\mathrm{Z}$ diperoleh $Z_{0=13,22}>Z_{0,05=1,64}$ maka Ho ditolak. Jadi, hasil rerata tes siswa adalah ada perbedaan. Maka berdasarkan deskripsi di atas, maka terlihat bahwa $\mathrm{Ha}$ diterima dan Ho ditolak, dimana statistik Ho : $\mu_{\mathrm{A} 1}=\mu_{\mathrm{A} 2}$ dan $\mathrm{Ha}: \mu_{\mathrm{A} 1}>\mu_{\mathrm{A} 2}$

\section{SIMPULAN DAN SARAN}

Berdasarkan hasil penelitian, maka dapat disimpulkan bahwa:

1. Kemampuan berpikir matematis dengan menggunakan analisis deskriptif penyekoran GRM, terlihat bahwa nilai interpretasi hasil belajar siswa ada 3 kategori yaitu interpretasi rendah, interpretasi sedang dan interpretasi tinggi. Ada 8 siswa dengan nilai interpretasi rendah, 27 siswa dengan nilai interpretasi sedang, dan 3 siswa dengan nilai interpretasi tinggi.

2. Hasil analisis nilai pretest dan posttest siswa terdapat perbedaan rerata hasil belajar siswa yaitu pretest 56,7 sementara posttest 78 . Berdasarkan adanya perbedaan tersebut dan menandakan hasil belajarnya meningkat, maka dapat disimpulkan bahwa penggunaan GRM efektif dalam menganalisis kemampuan berpikir matematis siswa terhadap butir soal.

\section{DAFTAR PUSTAKA}

Anderson, L. W., \& Krathwohl, D. R. (2010). Kerangka Landasan untuk Pembelajaran, Pengajaran, dan Asesmen (Revisi Taksonomi Bloom). Yogyakarta: Pustaka Pelajar.

Arikunto. (2001). Dasar-dasar evaluasi Pendidikan. Jakarta: Bumi Aksara.

Cornelius. (2000). Pentingnya Belajar Matematika. Jakarta: Balai Pustaka.

Depdiknas. (2005). Matematika Fungsi Matematika. Jakarta: DepdikbudDirjen Dikti.

Hake, R. R. (2002). Relationship of individual student normalized learning gains in mechanics with gender, high-school physics, and pretest scores on mathematics and spatial visualization. Physics Education Research Conference (Boise, IDE).

Matteuci, \& Staqcuarusi. (2006). Estimation of Latent Trait Ability Using a Response Pattern of Graded Scores. Psychometric Monograph.

Meltzer, D. . (2002). The Relationship between Mathematics Preparation and Conceptual Learning Grains in Physic: A Possible "Hidden Variable" in Diagnostice Pretest Scores. American Jounal Physics, 70(12), 17. 
Noer, S. . (2009). Peningkatan Kemampuan Berpikir Kritis Matematis Siswa SMP Melalui Pembelajaran Berbasis Masalah. In Seminar Nasional Matematika dan Pendidikan Matematika Jurusan Pendidikan Matematika FMIPA UNY. Yogyakarta: FMIPA UNY.

Sabandar, J. (2008). Thinking Classroom dalam Pembelajaran Matematika di Sekolah

Sanjaya. (2006). Komponen-komponen Materi Pelajaran. Surabaya: Erlangga.

Slameto. (2010). Belajar dan Faktorfaktor Yang Mempengaruhinya. Jakarta: Bineka Cipta.

Sugiyono. (2005). Statistika Untuk Penelitian. Bandung: Alfabeta.

Sugiyono. (2008). Metode-metode Penelitian. Bandung: Alfabeta.

Sugiyono. (210). Metode Penelitian Kuantitatf, Kualitatif, dan $R \& D$. Bandung: Alfabeta. 